\title{
Electric conductivity levels in irrigation water and application of biofertilizer in peanut $\mathrm{Br} 1$ crops
}

Lunara de Sousa Alves', Danila Lima de Araújo 2 , José Sebastião de Melo Filho ${ }^{2}$, Mário Leno Martins Véras ${ }^{3 *}$, Toni Halan da Silva Irineu ${ }^{4}$, Raimundo Andrade 5

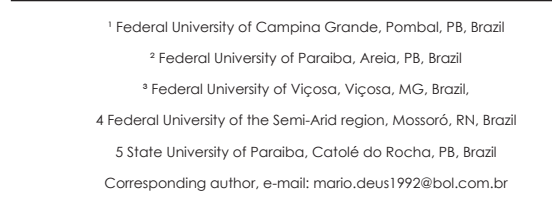

\begin{abstract}
Peanut is an oilseed cultivated in semiarid region. However, the lack of knowledge about irrigation and fertilization makes it difficult to increase its yield. Thus, the aim of this research was to study the effect of irrigation with water of different electrical conductivities and application of biofertilizer in peanut $\mathrm{Br}$. The research was carried out from August to November, 2014 at the State University of Paraíba - Campus IV, Brazil. The study was performed in a completely randomized design in a $4 \times 2$ factorial scheme, with four replicates. The treatments were related to different electrical conductivities in the irrigation water: $(S 1=0.8$; $\$ 2=1.5 ;$ S3 = 3; e $\$ 4=4.5$ $\mathrm{dS} \mathrm{m}^{-1}$ ) with and without biofertilizer application. It was verified that the electrical conductivity influenced significantly all analyzed variables, except root fresh mass. For biofertilizer application, according to the Tukey's test, only plant height and number of leaves were significantly influenced. Electrical conductivities in irrigation water above $0.8 \mathrm{dS} \mathrm{m}^{-1}$ reduce peanut growth and biomass production. The application of biofertilizer provides positive results in peanut cultivation in a Fluvic Neosol.
\end{abstract}

Keywords: : Arachis hypogaea L., water salinity, organic fertilizer.

\section{Introduction}

Peanut presents great economic relevance due to because of its ability to adapt to drought due to its morphological and physiological characteristics. In Northeast of Brazil, peanuts have been used in subsistence agriculture. However, although it is a rustic crop, due to climatic variations, the crop is exposed to several risks such as water deficit and low availability of good quality water (Graciano et. al, 2011).

Irrigation with saline water inhibits plant growth because it reduces the osmotic potential of the soil solution, since saline soils influence the plants affected by low water absorption by roots due to osmotic potential effects, restricting the availability of water and /or by excessive accumulation of ions in plant tissues. This may lead to ionic toxicity, nutritional imbalance or both (Lacerda et al., 2006; Sousa et al., 2010).

On the other hand, biofertilizer presents essential elements for the development of crops, reducing the use of chemical products, generating economy of inputs and improving the soil physical and biological attributes. In addition, bovine biofertilizer has been used as one of the management strategies that allows the exploration of areas irrigated with saline water in agriculture (Silva et al., 2011).

Sousa et al. (2012) showed that biofertilizer 
acts positively when interacting with water under different levels of salinity. Studying biofertilizer types at different levels of salinity in peanut crop, t was verified that bovine biofertilizer decreased the negative effects of the increasing concentrations of salts in the irrigation water for the the analyzed variables. Soil saline level was higher in the presence of anaerobic biofertilizer. The anaerobic biofertilizer was more efficient than aerobic in reducing depressant effects of irrigation water salts to the plants.

Thus, the aim of this research was to study the effect of irrigation with water of different electric conductivities and the application of biofertilizer in peanut $\mathrm{Br} 1$ crop.

\section{Materials and Methods}

The experiment was performed from August to November, 2014 in a greenhouse at the State University of Paraíba (UEPB), Center for Human and Agricultural Sciences (CCHA), Campus IV, located $2 \mathrm{~km}$ from Catolé do Rocha - PB, Paraíba 6020'38"S, 370 44'48"W and altitude of $275 \mathrm{~m}$.

The experiment was performed in a completely randomized design with a $4 \times 2$ factorial scheme, with 4 repetitions. The treatments consisted of the combination of electrical conductivity factor of irrigation water (ECa) $\left(\mathrm{S} 1=0.8 ; \mathrm{S} 2=1.5 ; \mathrm{S} 3=3\right.$ e S4 $\left.=4.5 \mathrm{dS} \mathrm{m}^{-1}\right)$ with and without biofertilizer application.

A Fluvic Neosol of sandy loam texture (Embrapa, 2013) mixed with earthworm humus (1:1) was used as substrate. Samples of $1 \mathrm{~kg}$ were collected in the 0 to $20 \mathrm{~cm}$ layer in a native area located at UEPB campus to perform the chemical analysis, according to Embrapa (1997) methodology, presenting the following characteristics: Sand= 63.90; Silt= 20.65; Clay= 15.45; Bulk density $=1.41 \mathrm{~g} \mathrm{~cm}^{-3}$; Saturation moisture $=23.16 \mathrm{~g} \mathrm{~kg}^{-1}$; Field capacity moisture $=$ $11.23 \mathrm{~g} \mathrm{~kg}^{-1}$; Wilting point moisture $=6.56 \mathrm{~g}$ $\mathrm{kg}^{-1} ; \mathrm{Ca}=4.63 \mathrm{cmolc} \mathrm{dm}^{-3} ; \mathrm{Mg}=2.39 \mathrm{cmolc} \mathrm{dm}^{-3}$; $\mathrm{Na}=0.30 \mathrm{cmol} / \mathrm{dm}^{-3} ; \mathrm{K}=0.76 \mathrm{cmolc} \mathrm{dm}^{-3} ; \mathrm{Sum}$

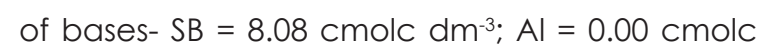
$\mathrm{dm}^{-3} ; \mathrm{CEC}=8.08$ and organic matter $=1.88 \%$. The elements were analyzed according to their extractors: $\mathrm{Ca}=\mathrm{KCl} 1 \mathrm{~mol} \mathrm{~L}^{-1} ; \mathrm{Mg}=\mathrm{KCl} 1 \mathrm{~mol} \mathrm{~L}^{-1}$; $\mathrm{Na}=$ Mehlich-1; $\mathrm{K}^{-}$Mehlich-1; $\mathrm{Al}=\mathrm{KCl} 1 \mathrm{~mol} \mathrm{~L}^{-1}$ and
Organic Matter: wet digestion.

The irrigation water showed an electrical conductivity of $0.8 \mathrm{dS} / \mathrm{m}$. The water analysis was performed by the Irrigation and Salinity Laboratory (LIS) of the Technology Center and Natural Resources of the Federal University of Campina Grande (UFCG), following the methodology proposed by Richards (1954) and presented the following chemical characteristics: $\mathrm{pH}=7.53 ; \mathrm{Ca}=2.30 \mathrm{cmolc} \mathrm{dm}^{-3} ; \mathrm{Mg}=1.56 \mathrm{cmolc}$ $\mathrm{dm}^{-3} ; \mathrm{Na}=4.00 \mathrm{cmolc} \mathrm{dm}^{-3} ; \mathrm{K}=0.02 \mathrm{cmolc} \mathrm{dm}^{-3}$; Chloride $=3.90 \mathrm{cmolc} \mathrm{dm}^{-3} ;$ Carbonate $=0.57$ cmolc dm dm $^{-3}$ Bicarbonate $=3.85 \mathrm{cmolc} \mathrm{dm}^{-3} ;$ RAS $=2.88($ mmolc -1$) 1 / 2$ and Richards Classification (1954).

The earthworm humus was submitted to chemical analysis according to Embrapa (1997) and presented the following characteristics: $\mathrm{pH} \mathrm{H} 2 \mathrm{O}(1: 2.5)=7.38$; Electrical Conductivity $=2.11 \mathrm{dS} \mathrm{m}^{-1} ; \mathrm{Ca}=3.54 \mathrm{cmolc} \mathrm{dm}^{-3} ; \mathrm{Mg}=1.93$ cmolc dm $3 ; \mathrm{Na}=0.18 \mathrm{cmolc} \mathrm{dm}^{-3} ; \mathrm{K}=0.14 \mathrm{cmolc}$ $\mathrm{dm}^{-3} ; \mathrm{S}=5.79 \mathrm{cmolc} \mathrm{dm}^{-3} ; \mathrm{H}=0.00 \mathrm{cmolc} \mathrm{dm}^{-3}$; Qualitative Calcium Carbonate $=$ present and $\mathrm{P}$ $=5.51 \mathrm{cmolc} \mathrm{dm}^{-3}$.

The bovine biofertilizer was obtained by anaerobic fermentation, that is, in a hermetically sealed environment. To release methane gas at the top of each biodigester, a thin hose was coupled to a far end and the other was immersed in a pot with water. Seventy $\mathrm{kg}$ of bovine manure from lactating cows and 120 liters of water were used to prepare the biofertilized, adding $5 \mathrm{~kg}$ of sugar and 5 liters of milk to accelerate bacteria metabolism (Silva, 2007).

After fermentation, the biofertilizer was diluted in water (1:1) and applied to plants in a volume equivalent to $10 \%$ of the substrate volume (1 L biofertilizer), within 8 days, with 8 applications. The organic input was analyzed using the irrigation water method proposed by Richards (1954) and presented the following characteristics: $\mathrm{pH}=4.68$; Electrical Conductivity $=4.70 \mathrm{dS} \mathrm{m}^{-1} ; \mathrm{N}=1 \mathrm{mg} \mathrm{dm}^{-3} ; \mathrm{P}=296.20 \mathrm{mg} \mathrm{dm}^{-3}$; $\mathrm{K}=0.71 \mathrm{mg} \mathrm{dm}^{-3} ; \mathrm{Ca}=3.75 \mathrm{mg} \mathrm{dm}^{-3} ; \mathrm{Mg}=3.30$ $\mathrm{mg} \mathrm{dm}^{-3} ; \mathrm{Na}=1.14 \mathrm{mg} \mathrm{dm}^{-3}$ and $\mathrm{S}=14.14 \mathrm{mg}$ $\mathrm{dm}^{-3}$.

The different levels of water salinity (CEa) were obtained by the addition of sodium chloride ( $\mathrm{NaCl}$ ) from the local supply system, according 
to Rhoades et al. (2000) and the salts content (Q) was determined by the equation:

$$
Q\left(\mathrm{mg} / \mathrm{L}^{-1}\right)=\text { CEa } \times 640
$$

In which, CEa (dS $\left.\mathrm{m}^{-1}\right)$ represents the desired value of water electrical conductivity. The water chosen as control - S1 $\left(0.8 \mathrm{dS} \mathrm{\textrm {m } ^ { - 1 } )}\right.$ comes from an amazon well located at UEPB.

The sowing was performed in pots with capacity of $10 \mathrm{~L}(0.18 \times 0.18 \mathrm{~m})$, drilled in the base to allow drainage. Soil was sieved in a $4 \mathrm{~mm}$ mesh and mixed with earthworm humus (1:1). Three peanut $\mathrm{Br} 1$ seeds were sown per pot and after 20 days, thinning was carried out, maintaining only the most vigorous plant.

The variables analyzed were: plant height, number of leaves, stem diameter, root fresh mass, stem fresh mass, leaf fresh mass, shoot fresh mass and total fresh mass.

The height measurements were made $30,50,70$ and 90 days after sowing (DAS). For this, a measuring tape graduated in $\mathrm{cm}$ was used in the distance between the transition from the root to stem and the apex of the plant. Leaf numbers were counted at 30, 50, 70 and 90 DAS. Measurements of stem diameter were performed at $30,50,70$ and 90 DAS with a digital caliper, two (2) $\mathrm{cm}$ above the begginign of the stem. Fresh matter remained approximately $48 \mathrm{~h}$ in forced circulation air oven at $60^{\circ} \mathrm{C}$ until constant weight, then root fresh mass, stem fresh mass, leaf fresh mass were weighed in with a precision of $0.0001 \mathrm{~g}$. Shoot fresh mass was obtained by the sum of stem and leaf fresh parts. The total fresh mass was obtained by the sum of all fresh parts of the plant (root, stem and leaf).

The effect of the different electrical conductivities of the irrigation water was evaluated through variance analysis, while the effect of the biofertilizer was accessed by the Tukey's test. The software SISVAR-ESALQ was used (Ferreira, 2011).

The effect of the different electrical conductivities of irrigation water was evaluated through analysis of variance, while the effect of the biofertilizer was performed by Tukey test. The software SISVAR was used (Ferreira, 2011).

\section{Results and Discussion}

In Table 3, it is observed that the different electrical conductivities in the irrigation water provided significance at $5 \%$ probability for plant height at 30 and 50 DAS, while at 90 DAS it presented a significance level of $1 \%$. The electrical conductivity in the irrigation water did not significantly influenced $\mathrm{PH}$ at 70 DAS. The adequate type of regression was linear for all variables. For biofertilizer application, only plant height up to 50 DAS with $5 \%$ level were statistically differentiated. There was no significant effect for

Table 3. Data from the analysis of variance regarding plant height in four growth stages (30,50, 70 and 90 DAS) under the effect of different electrical conductivities in irrigation water with and without application of biofertilizer. State University of Paraíba, Catolé do Rocha-PB, Brazil, 2014.

\begin{tabular}{|c|c|c|c|c|c|}
\hline \multirow{3}{*}{ Source of Variation } & \multirow[t]{3}{*}{ DF } & \multicolumn{4}{|c|}{ Plant Height (PH) } \\
\hline & & \multicolumn{4}{|c|}{ Mean Square } \\
\hline & & 30 DAS & 50 DAS & 70 DAS & 90 DAS \\
\hline Conductivity & 3 & $19.114^{*}$ & $54.20^{*}$ & $96.78^{\mathrm{ns}}$ & $451.78 * *$ \\
\hline Biofertilizer & 1 & $52.53^{*}$ & 98.0* & $15.3^{\mathrm{ns}}$ & $63.28 \mathrm{~ns}$ \\
\hline $\mathrm{C} \times \mathrm{B}$ Interaction & 3 & $10.11^{\mathrm{ns}}$ & $13.58^{\mathrm{ns}}$ & $9.36^{\mathrm{ns}}$ & $22.44^{\mathrm{ns}}$ \\
\hline Residue & 24 & 5.07 & 18.18 & 35.23 & 41.17 \\
\hline Coefficient of variation & (\%) & 26.6 & 21.94 & 20.19 & 15.22 \\
\hline
\end{tabular}

the interaction between electric conductivity $x$ biofertilizer.

It is observed that the different electrical conductivities in the irrigation water decreased as plant height ( $\mathrm{PH}$ ) increased (Figure 1A) at 30 , 50 and 90 DAS, whereas at 90 DAS it reached a level of $1 \%$. The highest values were found without salt addition (0.8 dS $\left.\mathrm{m}^{-1}\right)$ with maximum values of $10.62,22.5$ and $50.5 \mathrm{~cm}^{-1 a n t^{-1}}$ for plant height at 30,50 and 90 DAS, respectively, while the maximum level of $4.5 \mathrm{dS} \mathrm{m}^{-1}$ provided values of $7,16.25$ and 33.12 plant $^{-1}$ at 30,50 and 90 DAS, 
respectively.

Regarding biofertilizer application, only plant height at 30 and 50 DAS showed significance according to Tukey's test. In

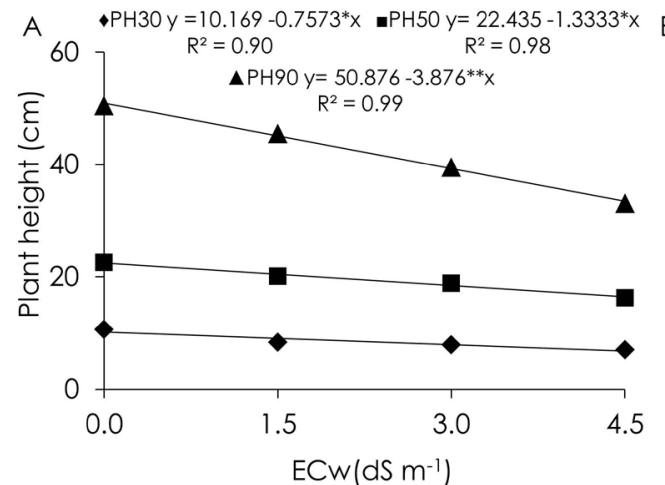

both, the highest result was observed with the application of biofertilizer providing 9.75 at 30 DAS and $21.18 \mathrm{~cm}^{\text {plant }}{ }^{-1}$ at 50 DAS, representing increments of 26.98 and $16.53 \%$ respectively,

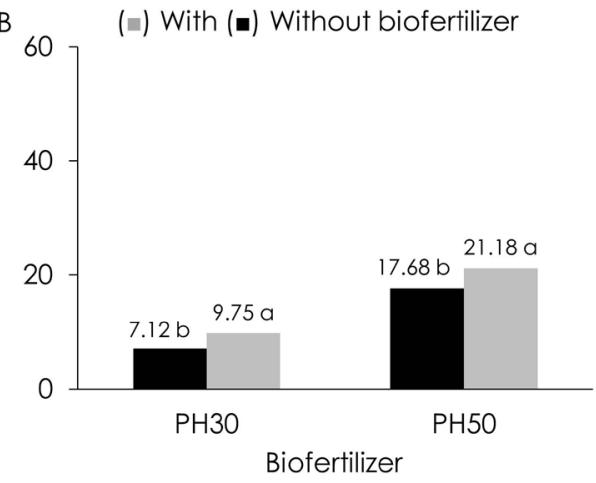

Figure 1. Plant height at 30,50 and 90 DAS under different electrical conductivities in irrigation water (A) and plant height at 30 and 50 DAS with and without biofertilizer application (B), State University of Paraíba, Catolé do Rocha - PB, 2014.

although no significance was observed in the other evaluations (70 and 90 DAS) (Figure 1B).

Similar results were found by Graciano et al. (2011) who studied increasing levels of salinity in the evaluations of different stages of peanut growth. They observed that higher salinity levels promoted a reduction in plant height. Gomes Filho et al. (2011), studying corn plants irrigated with high and low salinity under different spacings, observed a decrease in plant height with increased salinity of irrigation water. Santos et al. (2013), studying BRS Energia castor bean as a function of salinity of irrigation water (ECa: 0.12 to $4.8 \mathrm{dS} \mathrm{m}^{-1}$ ) found a reduction of $6.27 \%$ in plant height per unit of CEa increment.

Sousa et al. (2012) found similar results where the use of anaerobic biofertilizer in peanut crop stood out without the application and with the application of aerobic biofertilizer. Sousa et al. (2014) also observed similar results. A similar result was found by Lima et al. (2012), since the bovine biofertilizer increased plant height of corn plants.

Campos et al. (2011) found superiority in seedlings of yellow passion fruit seedlings under application of biofertilizer, obtaining a maximum value of $16.20 \mathrm{~cm}$ in the dose of $100 \%$.

Table 4 shows a significant effect of the different electrical conductivities in the irrigation water for the number of leaves at 30 and 90 DAS at $1 \%$ probability, adapting better to the linear regression type according to $F$ test. With of without the use of biofertilizer, it was found statistically significance according to Tukey test for all stages of growth (30, 50, 70 and 90 DAS), by $\mathrm{F}$ test at $1 \%$ and $5 \%$ probability. There was no

Table 4. Data from the analysis of variance regarding the number of leaves in four growth stages $(30,50,70$ and 90 DAS) under the effect of different electrical conductivities in irrigation water with or without biofertilizer application, State University of Paraiba, Catolé do Rocha - PB, 2014.

\begin{tabular}{|c|c|c|c|c|c|}
\hline \multirow[t]{3}{*}{ Source of variation } & \multirow[t]{3}{*}{ DF } & \multicolumn{4}{|c|}{ Number of leaves (NL) } \\
\hline & & \multicolumn{4}{|c|}{ Mean Square } \\
\hline & & 30 DAS & 50DAS & 70DAS & 90DAS \\
\hline Condutivity & 3 & $791.5^{* *}$ & $1265^{\mathrm{ns}}$ & $1990.4^{\text {ns }}$ & $11102^{* *}$ \\
\hline Biofertilizer & 1 & $1653.12^{* *}$ & $4418.0 *$ & $5832^{*}$ & $15886^{* *}$ \\
\hline $\mathrm{C} \times \mathrm{B}$ Interaction & 3 & $143.1^{\text {ns }}$ & $930.8^{n s}$ & $2294^{\text {ns }}$ & 1537 ns \\
\hline Residue & 24 & 147.10 & 836.6 & 1085 & 806 \\
\hline Coefficient of variation & (\%) & 25.33 & 24.42 & 18.78 & 12.37 \\
\hline
\end{tabular}

significant effect on the interaction between the electrical conductivity and fertilization.

It was verified significant effect at 30 and 90 DAS for the number of leaves, regarding the different electrical conductivities in the irrigation water. In both stages of growth the number of leaves decreased according to the increase of the conductivity level (0.8 dS $\left.\mathrm{m}^{-1}\right)$, with 61.5 and 
280.25 leaves at 30 and 90 DAS, respectively. With the addition of $4.5 \mathrm{dS} \mathrm{m}^{-1}$, there was a noticeable reduction in the number of leaves (37.7 and 190.5 leaves at 30 and 90 DAS, respectively), being possible to identify increments between the lowest and the greatest electrical conductivity (38.7 and $32.03 \%$, respectively, for 30 and 90 DAS).

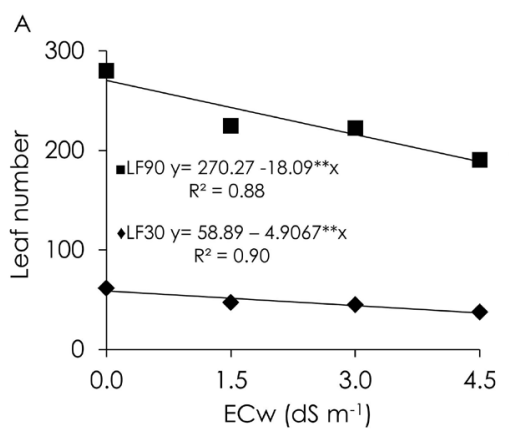

For the application of biofertilizer, it is possible to observe significance in all stages for number of leaves, where the best results were verified with the application of biofertilizer (Figure 2B), representing increments of $26.92,18.06,14.29$ and $17.68 \%$ when compared to treatment without the application, respectively at $30,50,70$ and 90 DAS.

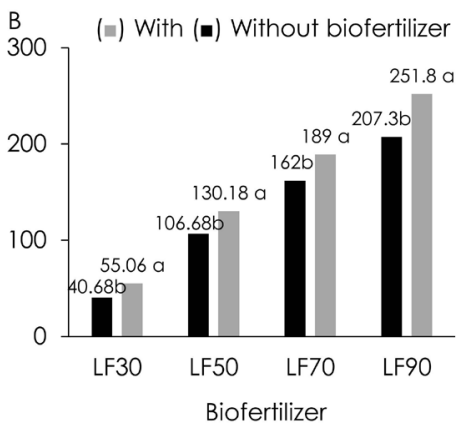

Figure 2. Number of leaves at 30 and 90 DAS under effect of different electrical conductivities (A) and number of leaves at 30,50 , 70 and 90 DAS with and without biofertilizer application (B), State University of Paraíba, Catolé do Rocha - PB , 2014.

In order to analyze the growth of peanut cultivars (BR 1 and BRS 151 L7) at different levels of salinity (electrical conductivity of irrigation water: 0.4, 1.5, 3.0; Correia et al., (2009) observed a significant decrease in number of leaves. Sousa et al., (2012) also observed significant decrease

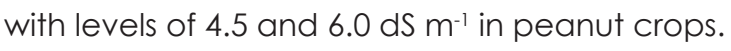

Medeiros et al. (2011), studying cherry tomatoes, also observed a higher number of leaves at lower salinity levels even with biofertilizer. Oliveira et al. (2011) found that the increase of water CEa caused a reduction in the number of leaves in lettuce. On the other hand, Graciano et al. (2011) did not find significant difference when studied different salinity levels.

Similar results were observed by Sousa et al. (2012), who verified the best results with the application of anaerobic biofertilizer in peanut crop. Chiconato et al. (2013), studying lettuce using biofertilizer also verified positive results with the highest dose $\left(60 \mathrm{~m}^{3} \mathrm{ha}^{-1}\right)$.

The decrease in number of leaves under salinity stress conditions is one of the alternatives that the plant has to maintain a balanced water absorption, resulting in morphological and anatomical changes, leading to transpiration reduction (Oliveira et al. 2011).

The results shown in Table 5 represent the stem diameter in four stages of growth at 30, 50, 70 and 90 DAS, and it can be verified that the different electrical conductivities in the irrigation water had a significant influence on all stages of the diameter and all behaved linearly according to the statistical results (Test F). No significant effects were observed for the biofertilizer factor. The conductivity $x$ biofertilizer interaction did not present statistical significance.

Table 5. Data from variance analysis regarding stem diameter in four stages of growth (30,50, 70 and 90 DAS), under the effect of different electrical conductivities in irrigation water with and without biofertilizer application, State University of Paraíba, Catolé do Rocha - PB, 2014.

\begin{tabular}{|c|c|c|c|c|c|}
\hline \multirow[t]{2}{*}{ Source of variation } & \multirow[t]{3}{*}{ DF } & \multicolumn{4}{|c|}{ Stem diameter (SD) } \\
\hline & & \multicolumn{4}{|c|}{ Mean Square } \\
\hline & & 30 DAS & $50 \mathrm{DAS}$ & 70DAS & 90DAS \\
\hline Conductivity & 3 & $1.50^{*}$ & $0.86^{*}$ & $1.11^{* *}$ & $2.54^{* *}$ \\
\hline Biofertilizer & 1 & $0.20^{\mathrm{ns}}$ & $0.03^{n s}$ & $0.03^{n s}$ & $0.89^{\mathrm{ns}}$ \\
\hline $\mathrm{C} \times \mathrm{B}$ Interaction & 3 & $0.16^{\mathrm{ns}}$ & $0.28^{\mathrm{ns}}$ & $0.86^{\mathrm{ns}}$ & $0.83^{\text {ns }}$ \\
\hline Residue & 24 & 0.37 & 0.30 & 0.28 & 0.50 \\
\hline Coefficient of Variation & (\%) & 17.5 & 13.43 & 11.54 & 13.63 \\
\hline
\end{tabular}


The best values were without the use of high electrical conductivity water $\left(0.8 \mathrm{dS} \mathrm{m}^{-1}\right)$ with approximately 3.87 (30 DAS), 4.37 (50 DAS), 5 (70 DAS) and $5.87 \mathrm{Mm}^{\text {plant }}{ }^{-1}$ (90 DAS), observing a significant decrease compared to the maximum

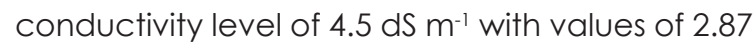
(30 DAS), 3.62 (50 DAS), 4.12 (70 DAS) and $4.5 \mathrm{~mm}$ plant $^{-1}$ (90 DAS) (Figure 3).

Graciano et al. (2011) observed decreases in stem diameter with saline irrigation in peanuts. Campos et al. (2009), studying castor bean, also verified that the stem diameter presented a reduction when submitted to water salinity. However, the results were always superior in treatments with biofertilizer.

Sousa et al., (2012), studying salinity levels and types of biofertilizers, found similar results with decrease in stem diameter according to high

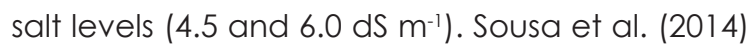
found a significant reduction in stem diameter of peanut plants with the use of high levels of salinity.

According to Garcia et al. (2010), the increase of salinity levels in the soil possibly influences the reduction of soil matrix potential, and may cause difficulties for the plants to absorb water. They also reported that the increase in osmotic pressure in the soil can reach values where the plants will not have sufficient suction forces to overcome the soil potential.

Saline stress causes inhibition of plant growth in stem diameter due to the osmotic effect of saline irrigation water, which reduces water absorption (Sousa, et al., 2014).

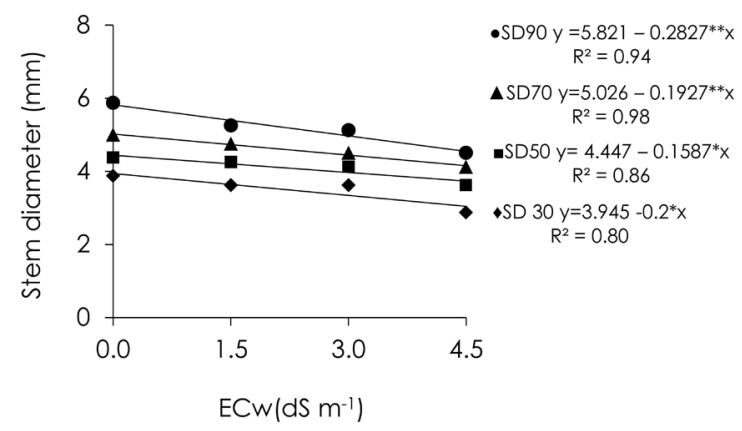

Figure 3. Stem diameter at 30,50, 70 and 90 DAS under different electrical conductivities in irrigation water, State University of Paraíba, Catolé do Rocha-PB, 2014.

Table 6. Data of the variance analysis regarding stem fresh mass (SFM), leaf fresh mass (LFM), root fresh mass (RFM), shoot fresh mass (SFM) and total fresh mass (TFM) under the effect of different electrical conductivities in irrigation water with and without biofertilizer application. State University of Paraíba, Catolé do Rocha - PB, 2014.

\begin{tabular}{|c|c|c|c|c|c|c|}
\hline Source of Variation & DF & & Mean & Square & & \\
\hline & & SFM & LFM & RFM & SFM & TFM \\
\hline Conductivity & 3 & $865.2^{* *}$ & $2463.5^{* *}$ & $4.94^{\mathrm{ns}}$ & $6176.1^{\text {** }}$ & $6366.5^{* *}$ \\
\hline Biofertilizer & 1 & $185.2^{\mathrm{ns}}$ & $378.12^{\text {ns }}$ & $38.28^{\mathrm{ns}}$ & $1092.7^{\mathrm{ns}}$ & $1540.1^{\text {ns }}$ \\
\hline $\mathrm{C} \times \mathrm{B}$ Interaction & 3 & $151.5^{\text {ns }}$ & 384.37 ns & $52.86^{\text {ns }}$ & $956.1 \mathrm{~ns}$ & $1261.3^{\mathrm{ns}}$ \\
\hline Residue & 24 & 62.15 & 319.7 & 58.07 & 578.9 & 813.1 \\
\hline $\mathrm{CV}$ & $(\%)$ & 22.39 & 31.27 & 31.47 & 26.04 & 24.45 \\
\hline
\end{tabular}

It can be observed in Table 6 that the different electrical conductivities in the irrigation water influenced the fresh mass of the stem, leaf and shoot with a $1 \%$ of significance level, being better adjusted in a linear regression. For the biofertilizer application influence, it was not observed significant effects for the evaluated variables and the same was observed for the interaction between the factors electrical conductivity $x$ biofertilizer.
It is observed that stem and leaf fresh mass were influenced significantly by the electrical conductivity in the irrigation water, with linearity with decreasing behavior. As the electrical conductivity increased in the irrigation water, stem and fresh mass descreased, reaching the minimum values at the level of $4.5 \mathrm{dS} \mathrm{m}^{-1}$ with approximately 25.62 (SFM) and 38.12 (LFM),

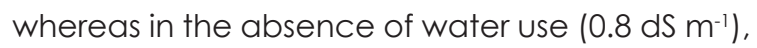
the results of $50 \mathrm{~g} \mathrm{plant}^{-1}$ (SFM) and $80 \mathrm{~g} \mathrm{plant}^{-1}$ 
(LFM) were observed (Figure 4). Santos Júnior et al. (2011) found similar results, which showed a significant reduction of stem and leaf fresh mass when high salinity levels of 9.0 and 11.5 were applied in sunflower crops.

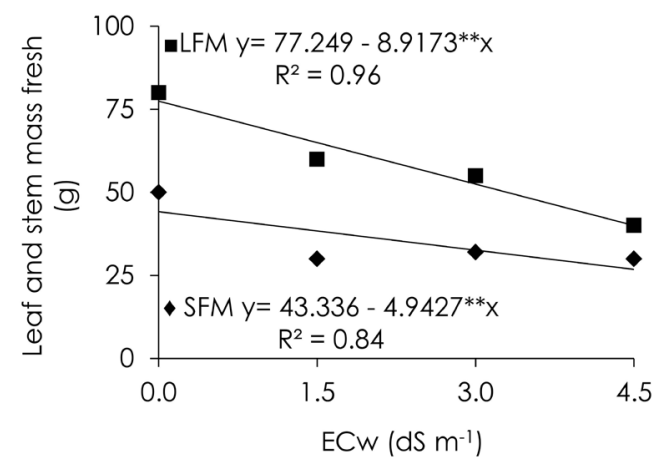

Figure 4. Stem fresh mass (SFM) (A) and leaf fresh mass (LFM) (B), under the effect of different electrical conductivities in the irrigation water, State University of Paraíba, Catolé do Rocha - PB, 2014
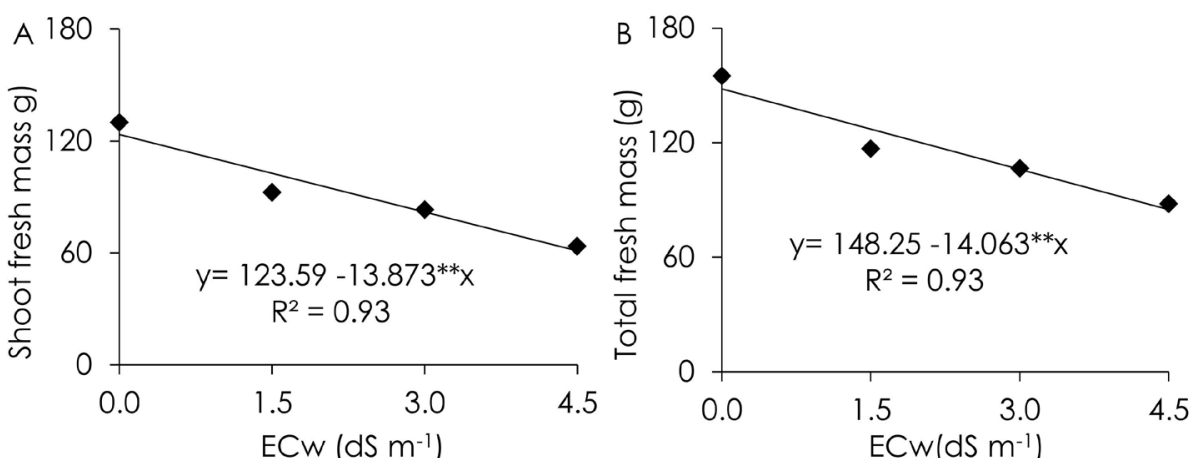

Figure 5. Shoot fresh mass (A) and total fresh mass (B) under different electrical conductivities in the irrigation water, State University of Paraíba, Catolé do Rocha - PB, 2014

The growth inhibition was caused by the toxic effects of the salts absorbed by the plants, by the reduction of the osmotic adjustment capacity of the crop and by the reduction of water total potential caused by the increase of salinity concentration (Lacerda et al., 2006; Silva et al., 2011).

Shoot fresh mass and total fresh mass (Figure 5A and 5B) behaved the same way, showing a difference between the minimum electrical conductivity and the maximum and maximum electrical conductivity of $4.5 \mathrm{dS} \mathrm{m} \mathrm{m}^{-1}$, resulting in increases of $51 \%$ and $43.15 \%$ for shoot fresh mass and total fresh mass, respectively. Shoot fresh mass of sunflower plants was significantly influenced by the increase of salinity levels, resulting in decrease (Santos Júnior, et al., $2011)$.

The growth inhibition was possibly due to the toxic effects of salts absorbed by the plants, by the reduction of osmotic adjustment capacity and the reduction of total water potential caused by the increase of salinity concentration (Lacerda et al., 2006; Silva et al., 2011).

\section{Conclusions}

Electrical conductivities in irrigation water above $0.8 \mathrm{dS} \mathrm{m}^{-1}$ reduce peanut growth and biomass production.

The application of biofertilizer provides positive results in peanut cultivation in Fluvic Neosol.

\section{References}

Campos, V. B. Cavalcante, L. F.; Rodolfo Júnior, F.; Sousa, G. G.; Mota, J. K. 2009. Crescimento inicial da mamoneira em resposta à salinidade e biofertilizante bovino. Revista Magistra 21: 41-47.

Campos, V. B.; Cavalcante, L. F.; Campos, S. S. P.; Chaves, L. H. G.; Mesquita, F. O. 2011 . Esterco bovino líquido em luvissolo sódico: I. Resposta biométrica e produtiva do maracujazeiro amarelo. Idesia 29: 59-67.

Cavalcante, L. F.; Vieira, M. S.; Santos, F.; Oliveira, W. M.; Nascimento, J. A. M. 2010. Água salina e 
esterco bovino líquido na formação de mudas de goiabeira cultivar paluma. Revista Brasileira de Fruticultura 32: 251-261.

Chiconato, D. AP.; Simoni, F. de; Galbiatti, J. A.; Franco, C. F.; Caramelo, A. D. 2013. Resposta da alface à aplicação de biofertilizante sob dois níveis de irrigação. Bioscience Journal 29: 392399.

Correia, K. G.; Fernandes, P. D.; Gheyi, H. R.; Nobre, R. G.; Santos, T. S. 2009. Crescimento, produção e características de fluorescência da clorofila a em amendoim sob condições de salinidade. Revista Ciência Agronômica 40: 514521.

Embrapa. Centro Nacional de Pesquisa de Solos (Rio de Janeiro, RJ). 1997. Manual de métodos de análise de solo. 2.ed. rev. atual. Rio de Janeiro. $212 \mathrm{p}$.

Embrapa. Sistema brasileiro de classificação de solos. 2013. 3 ed. Brasília, DF: Embrapa. 353 p.

Ferreira, D. F. 2011 . Sisvar: A computer statistical analysis system. Ciência e Agrotecnologia 35: 1039-1042.

Garcia, G. O.; Nazário, A. A.; Moraes, W. B.; Gonçalves, I. Z.; Madalão, J. C. 2010. Respostas de genótipos de feijoeiro á salinidade. Engenharia na Agricultura 18: 330-338.

Gomes, K. R.; Amorim, A. V.; Ferreira, F. J.; Filho, F. L.; Lacerda, C. F.; Gomes-Filho, E. 2011 . Respostas de crescimento e fisiologia do milho submetido a estresse salino com diferentes espaçamentos de cultivo. Revista Brasileira de Engenharia Agrícola e Ambiental 15: 365-370.

Graciano, E. S. A.; Nogueira, R. J. M. C.; Lima, D. R. M.; Pacheco, C. M.; Santos, R. C. 2011. Crescimento e capacidade fotossintética da cultivar de amendoim BRI sob condições de salinidade. Revista Brasileira de Engenharia Agrícola Ambiental 15: 794-800.

Lacerda, C. F. Assis Júnior, L. O.; Lemos Filho, L. C. A.; Oliveira, T. S.; Guimarães, F. V. A.; Gomes Filho, E.; Prisco, J. P.; Bezerra, M. A. 2006. Morphophysiological responses of cowpea leaves to salt stress. Brazilian Journal Plant Physiology18: 455465.

Medeiros, R. F. Cavalcante, L. F.; Mesquita, F. O.; Rodrigues, R. M.; Sousa, G. G.; Diniz, A. A. 2011. Crescimento inicial do tomateiro-cereja sob irrigação com águas salinas em solo com biofertilizantes bovino. Revista Brasileira de Engenharia Agrícola e Ambiental 15: 505-511.
Mesquita, F. O.; Cavalcante, L. F.; Rebequi, A. M.; Lima Neto, A. J. DE.; Nunes, J. C.; Nascimento, J. A. M. dos. 2010. Produção de mudas de maracujazeiro amarelo em substrato com biofertilizante bovino irrigado com águas salinas. Revista Agropecuária Técnica 31: 1-9.

Oliveira, F. A.; Carrilo, M. J. S.; Medeiros, J. F.; Maracá, P. B.; Oliveira, M. K. T. 2011 . Desempenho de cultivares de alface submetidas a diferentes níveis de salinidade da água de irrigação. Revista Brasileira de Engenharia Agrícola e Ambiental 15: 771-777.

Rhoades, J. D.; Kandiah, A.; Mashali, A. M. Uso de águas salinas para produção agrícola. 2000. UFPB: Campina Grande - PB, Brasil, 117p. (Estudos FAO. Irrigação e drenagem, 48).

Richards, L. A. 1954. Diagnosis and improvement of saline and alkali soils. Department of Agriculture: Washington: U. S., 160p.

Santos Júnior, J. A.; Gheyi, H. R.; Guedes Filho, D. H.; Dias, N. S. Soares, F. A. L. 2011. Cultivo de girassol em sistema hidropônico sob diferentes níveis de salinidade. Revista Ciência Agronômica 42: 842-849.

Santos, J. B. dos; Santos, D. B. dos; Azevedo, C. A. V. de; Rebequi, A. M.; Cavalcante, L. F.; Cavalcante, I. H. L. 2013. Comportamento morfofisiológico da mamoneira BRS Energia submetida à irrigação com água salina. Revista Brasileira de Engenharia Agrícola e Ambiental 17: 145-152.

Silva, F. L. B.; Lacerda, C. F.; Sousa, G. G.; Neves, A. L. R.; Silva, G. L.; Sousa, C. H. C. 2011 . Interação entre salinidade e biofertilizante bovino na cultura do feijão-de-corda. Revista Brasileira de Engenharia Agrícola e Ambiental 15: 383-389.

Silva, A. F.; Pinto, J. M.; França, C. R. R. S.; Fernandes, S. C.; GOMES, T. D. A.; SILVA, M. S. L. da, ANB, M. 2007. Preparo e uso de biofertilizantes líquidos. Embrapa Semi-Árido. Comunicado técnico.

Sousa, G. G.; Azevedo, B. M.; Mesquita, J. B. R.; Viana, T. V. A. 2012. Características agronômicas do amendoinzeiro sob irrigação com águas salinas em solo com biofertilizantes. Revista Agro@mbiente On-line 6: 124-132.

Sousa, G. G.; Lacerda, C. F.; Cavalcante, L. F.; Guimarães, F. Y. A.; Bezerra, M. E. J.; Silva, G. L. 2010. Nutrição mineral e extração de nutrientes de planta de milho irrigada com água salina. Revista Brasileira de Engenharia Agrícola e Ambiental 14: 1143-1151. 
Véras et al. (2017) / Electric conductivity levels in irrigation ...

Sousa, G. G.; Lima, F. A.; Gomes, K. R.; Viana, T.

V. A.; Costa, F. R. B.; Azevedo, B. M.; Martins, L. F.

2014. Irrigação com água salina na cultura do

amendoim em solo com biofertilizante bovino.

Nativa 2: 89-94 